\title{
COMPARISON OF THE DIMENSIONS DESIGN METHODOLOGIES OF THE RAILWAY TRACK BED STRUCTURE ACCORDING TO FROST EFFECT IN SLOVAKIA AND LITHUANIA
}

\author{
Libor IŽVOLT ${ }^{1}$, Peter DOBEŠ ${ }^{1}$, Deividas NAVIKAS ${ }^{2}, 3^{*}$ \\ ${ }^{1}$ Department of Railway Engineering and Track Management, University of Žilina, Žilina, Slovakia \\ ${ }^{2}$ Department of Mobile Machinery and Railway Transport, Vilnius Gediminas Technical University, \\ Vilnius, Lithuania \\ ${ }^{3}$ Department of Automobiles Transport Engineering, Vilnius Technology and Design College, Vilnius, Lithuania
}

Received 19 January 2019; accepted 08 May 2019

\begin{abstract}
This paper compares methods of designing the track bed structure that are used in the processes of design and review design of subgrade tracks located in Slovakia and Lithuania. Self-comparison is made on a particular type of track bed with the aim to highlight the differences between individual countries methodologies that affect not only the dimension of the sub-ballast layer, but also economic demands and reliability of the design of railways structure.
\end{abstract}

Keywords: ballast bed, non-transport railway track loading, sub-ballast, thermal regime, frost depth, thickness.

\section{Introduction}

The railway of a rail vehicle, that consists of rails, sleepers, track fittings, ballast bed (that together form the railway superstructure), the body of the subgrade and its objects (that together constitute the track substructure), must be sufficiently deformation-resistant and must adequately resist the effects of a number of negative operating factors (Bai, Liu, Sun, Wang, \& Xu, 2015; Navikas, Bulevičius, \& Sivilevičius, 2016). Behavior and reactions of the body of track substructure are different; depending on the size and nature of the stress loading by rail vehicles and railway superstructure as well as the status and nature of the track substructure (Navikas \& Sivilevičius, 2017; Nguyen, Goicilea, \& Galbadon, 2014). In operating conditions, the actual track loading is characterized as a very diverse load of axle or wheel forces of individually moving rail vehicles or trains for goods and passenger transport (Giner, Alvarez, Garcia-Moreno, \& Camacho, 2016; Nguyen et al., 2014). Moving rail vehicles or trains themselves apply a load to the track structure - track skeleton, ballast bed and their foundation by complex force effects of static, quasistatic and dynamic nature (Gu \& Choi, 2013). Static and dynamic load altogether compose the so-called transport railway track loading (AB "Lietuvos geležinkeliai" [LG],
2013; Directorate General of the Railways of the Slovak Republic, 2005).

In addition to these direct loading effects by rail vehicles the structure of the railway track is also being exposed to other effects, particularly to weather and climate actions (water, frost, solar radiation and wind) causing thermal effects of rail strings and changes in the thermal conductivity regime of the subgrade surface (Yang et al., 2015; Ižvolt, Dobeš, \& Pultznerová, 2016). These weather and climatic influences are so-called non-transport railway track loading (LG, 2013; Directorate General of the Railways of the Slovak Republic, 2005).

It is obvious that if we want the railway track to show the required technical characteristics in a long term, it must sufficiently be able to withstand the transport and non-transport loading. The structural arrangement and dimensions of the structural layers of the body of track substructure, dimensions and shapes of the body of railway substructure have to ensure, in order to maintain permanent structural arrangement of the track, the desired crush resistance and stability to the railway superstructure, which is essential for safe and reliable railway, and thus smooth railway operations (Bureika, Gaidamaus-

\footnotetext{
*Corresponding author. E-mail: deividas.navikas@vgtu.lt
} 
kas, Kupinas, Bogdevičius, \& Steišūnas, 2016; Podvezko \& Sivilevičius, 2013; Ižvolt, 2008).

Following the study internship of MSc. Deividas Navikas of Vilnius Gediminas Technical University at the Žilina University, Department of Railway Engineering and Track Management (DRETM) (Slovakia) in the summer semester of the academic year 2015/2016 and due to the fact that in addition to other issues of railway engineering that are being addressed and solved at the DRETM has also been addressing the issues of non-transport railway track loading for long, the authors of the article have decided that it would be for both parties useful, inspiring, and thus possibly helpful to compare methods of designing of track bed (TB) structure with the aim to verify and eventually adapt the currently existing methods of the TB structure dimensions design methodology due to the adverse effects of frost used on railway tracks in Slovakia, which have been administered by the Railways of the Slovak Republic (ŽSR), or those in Lithuania, administered by the Railways of Lithuania (AB "Lietuvos geležinkeliai“ - LG).

\section{Background for the conceptual framework and content facet of the paper}

The basics of the design methodology of TB structure used for railway tracks of the ŽSR, which are included in the railway technical standard TNŽ 73 6312:2005 (Directorate General of the Railways of the Slovak Republic, 2005), were laid back in the 70 s of the 20th century and are therefore influenced by the level and state of knowledge of the issue during its creation phase. Considering the fact that our knowledge in the field of transport and non-transport loads are being gradually supplemented by new information, and due to the fact that in the late 90 s of the 20th century there began in Slovakia the modernization of railway tracks included in the trans-European corridors in accordance with the AGC (European Agreement on Main International Railway Lines), AGTC (European Agreement on Important International Combined Transport Lines and Related Installations) and following the concept of trans-European networks TEN, or TEN-T, it has been shown as even more desirable, to proceed to the amendment of the methodology described in TNŽ 73 6312:2005 (Directorate General of the Railways of the Slovak Republic, 2005).

At DRETM the issue of non-transport loading has already been examined with intense interest since 2003 . For this purpose, there have been two railway track models built: Experimental stand of DRETM I (Figure 1) and the one built in 2013 - Experimental stand of DRETM II (Figure 2). Both of them serve not only to verify the design methods of TB structure for non-transport loading (structural thickness of the sub-ballast layer), but also to verify the depth calculation of freeze value in the structure of the railway track and design values of thermal conductivity coefficient $(\lambda)$ (Ižvolt, Dobeš, \& Pitonak, 2017).

By acquisition of the software product SOILVISION in 2014, which is designed for mathematical modeling of non-transport loading affected on the railway track, along with the knowledge gained through experimental measurements of thermal regime in respective winter seasons of $2003 / 2004$ to $2015 / 2016$ on the relevant experimental stands and in laboratory conditions verified cofactors of thermal conductivity $(\lambda)$ of building materials currently used in structural layers of the railway track, we have gradually acquired new knowledge and skills in the field of non-transport railway track loading and thus enough sufficient input to the already mentioned need to amend the railway technical standard TNŽ 73 6312:2005 (Directorate General of the Railways of the Slovak Republic, 2005).

So far from that for a long period of time conducted research on non-transport load at DRETM and the results obtained we have been able to identify what is needed to be amended, modified or supplemented within TNŽ 73 6312:2005 (Directorate General of the Railways of the Slovak Republic, 2005) methodology.

Furthermore, based on the deep interest of the $\mathrm{PhD}$ student MSc. Deividas Navikas and in order maximally utilize available conditions for his scientific work on the doctoral dissertation thesis it has also been decided to confront the newfound information with foreign resources, whereas for the purpose of the particular comparison of the structure dimensions design methodology of TB methodology used at Lithuanian has been applied here.

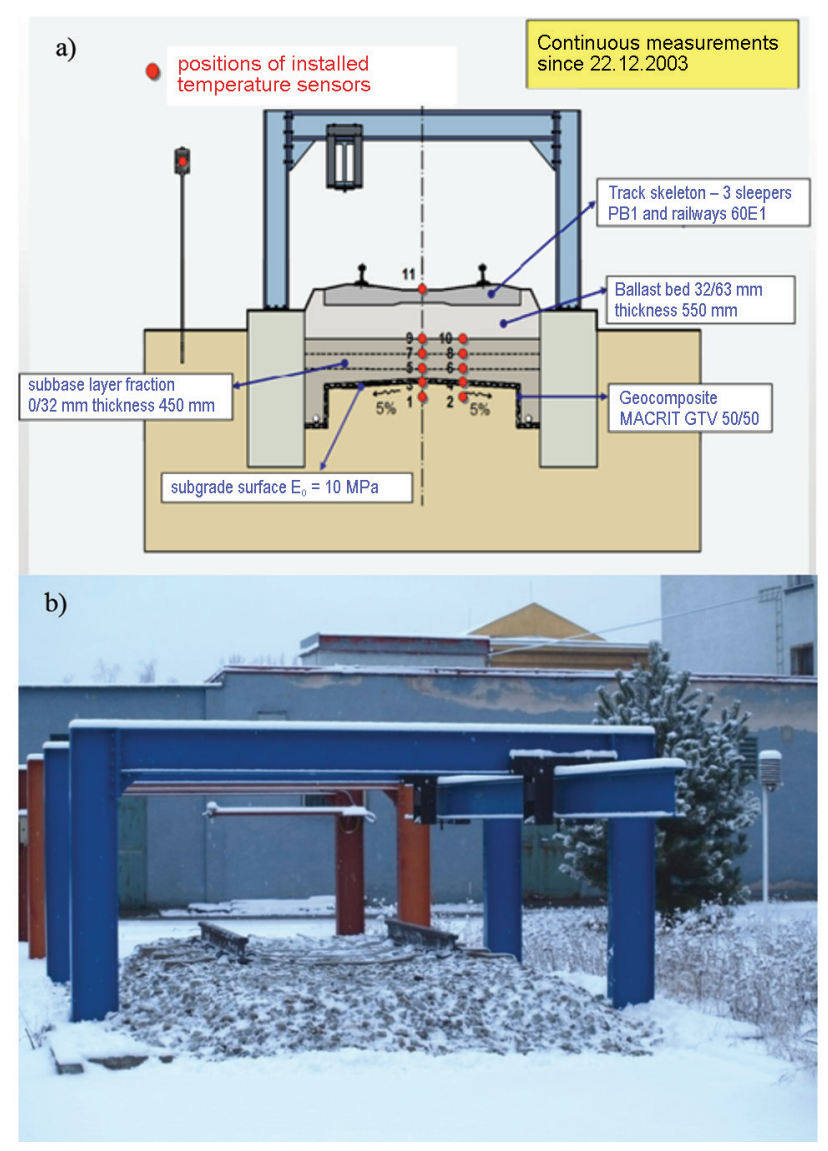

Figure 1. Experimental stand of DRETM I: a) a cross section of the experimental stand; b) the view of the experimental stand construction (Ižvolt, Dobeš, \& Pitoňák, 2014) 


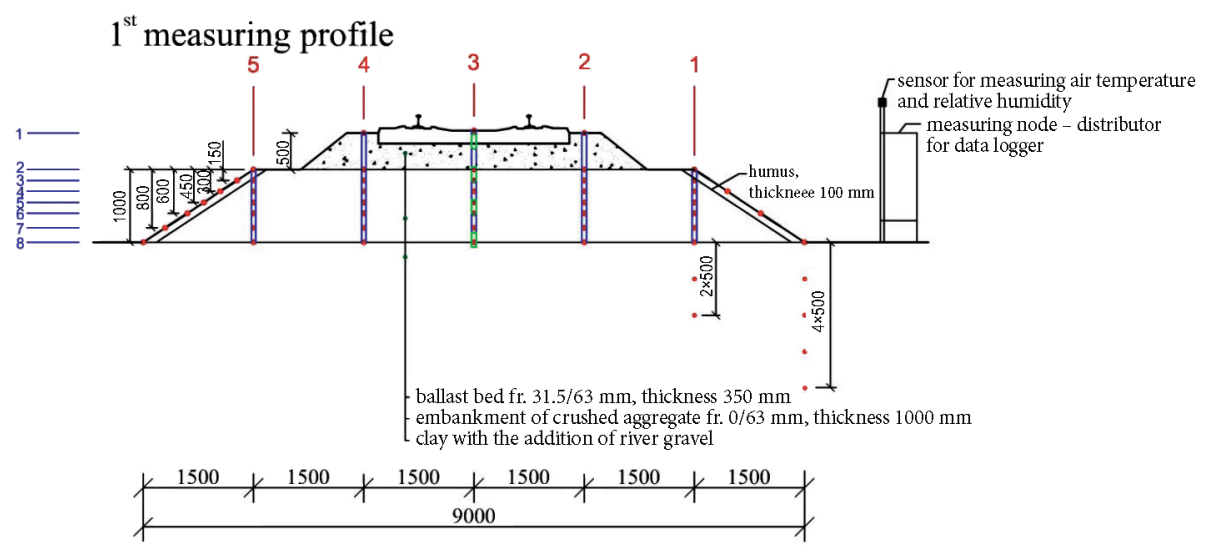

a)

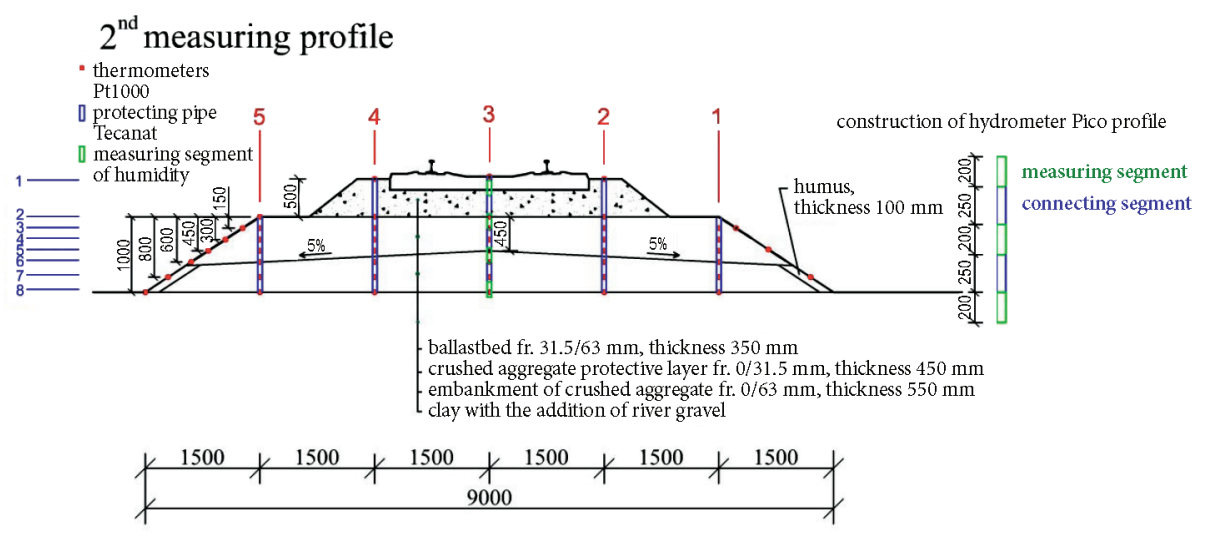

b)

Figure 2. Experimental stand of DRETM II: a) plan view of the experimental stand, b) cross sections of the experimental stand (Ižvolt \& Dobeš, 2015)

\section{Comparison of the design methodologies for determination of the required thickness of sub-ballast layer}

For comparison of designs of the required structural thickness of the sub-ballast layer based upon methodologies applied in Slovakia and Lithuanian we have selected the route category P 160 (M 160) - Passenger transport route (Mixed transport routes) for railways of Lithuania tracks, corresponding with the Slovak category for the velocity range VR 4 (design velocity $120 \mathrm{~km} / \mathrm{h}<V \leq 160 \mathrm{~km} / \mathrm{h}$ ). The comparison of design of the minimum required thickness of the sub-ballast layer in terms of transport and nontransport load is specified in Table 1.

The comparison of the required values of structural thickness of the sub-ballast layer shown in Table 1 can be made only with difficulty because the design nomograms used by both railway administrations are not only designed for the same input parameters, but also the design methodology for determination of values of static modules of deformation differ. The result of static load tests on identical test surface is not, because of the differences in test methodologies, an identical value of deformation modulus and there is no known correlation coefficient between the static deformation modulus according to the methodology described in STN 736190 (Slovak Office of Standards, Metrology and Testing, 1980) and according to the methodology described in DIN 18134 (Deutsches Institut für Normung, 1993). Moreover, the methodology used in Slovakia considers values of deformation resistance of the railway subbase material in the range 90 to $120 \mathrm{MPa}$ (in case of a new structure), or in the range 60 to $90 \mathrm{MPa}$ (in the case of an existing track), which makes that we do not receive only one value of the desired thickness of the layer as it is in case of the methodology used in Lithuania. For the above mentioned reasons, the values of structural thickness of the sub-ballast layer differ, whereas it can be concluded that the lower limits of structural thicknesses are about the same.

\section{Mathematic modeling boundary conditions and results}

The comparison from the aspect of non-transport load is also difficult to be performed because the territory of Lithuania is not divided into different zones in terms of intensity of winter seasons, although in the design table described in DS 836 (Deutsche Bundesbahn, 1999) there are three frost 
Table 1. Required minimum thickness of the sub-ballast layer according to the methodologies in Slovakia and Lithuania

\begin{tabular}{|c|c|c|c|c|c|}
\hline \multirow{2}{*}{$\begin{array}{c}\text { Railway } \\
\text { administration }\end{array}$} & \multirow{2}{*}{$\begin{array}{l}\text { Considered } \\
\text { track }\end{array}$} & \multicolumn{2}{|c|}{ Required static deformation modulus, $\mathrm{MPa}$} & \multicolumn{2}{|c|}{$\begin{array}{l}\text { Minimum thickness of } \\
\text { sub-ballast layer, } d_{\mathrm{pl}, \mathrm{min}}, \mathrm{m}\end{array}$} \\
\hline & & $\begin{array}{l}\text { of the sub-ballast } \\
\text { upper surface } E_{\mathrm{PPL}, \min }\end{array}$ & $\begin{array}{l}\text { of the surface level of the } \\
\text { substructure body } E_{\mathrm{PL}, \mathrm{min}}\end{array}$ & $\begin{array}{l}\text { For transport } \\
\text { load } \\
\end{array}$ & $\begin{array}{c}\text { For non- } \\
\text { transport load }\end{array}$ \\
\hline \multirow{2}{*}{$\begin{array}{l}\text { ŽSR } \\
\text { TNŽ } 73 \text { 6312:2005 } \\
\text { (Directorate General } \\
\text { of the Railways of the } \\
\text { Slovak Republic, 2005) }\end{array}$} & $\begin{array}{l}\text { new structure } \\
\text { (modernized) }\end{array}$ & 40 & 80 & $0.30-0.50^{*}$ & 0.60 \\
\hline & reconstructed & 30 & 50 & $0.20-0.40^{*}$ & 0.60 \\
\hline \multirow{2}{*}{$\begin{array}{l}\text { LG (Apsauginio ..., } \\
\text { 2013) }\end{array}$} & $\begin{array}{l}\text { new structure } \\
\text { (modernized) }\end{array}$ & 40 & 80 & 0.25 & 0.60 \\
\hline & reconstructed & 30 & 50 & 0.20 & 0.30 \\
\hline
\end{tabular}

Note: * structural thickness depends on the grading of the railway subbase material used or on the deformation modulus of the sub-ballast layer material.

areas considered. Therefore, in terms of non-transport load the comparison was carried out for the frost index $\left(I_{\mathrm{F}}=-650^{\circ} \mathrm{C} \cdot\right.$ day $)$ that represents the maximum frost index reached at the territory of Lithuania set for the winter season 1985/1986 at the weather station in Dūkštas (measured value $I_{F}=-633{ }^{\circ} \mathrm{C}$.day). The stated frost index value corresponds approximately with the frost index of Slovakia set at the weather station Poprad for the winter season $1995 / 1996$ (measured value $I_{F}=-663{ }^{\circ} \mathrm{C} \cdot$ day).

Consequently, for further comparison of the required thickness of the sub-ballast layer the experimental stand shown in Figure 2 was applied in which we performed mathematical modeling of thermal regime of classical (gravel) structure of TB utilizing available software SoilVision, namely its product SVHeat, characterized in detail in Dobeš (2015), and SoilVision systems Ltd. (2009). The software was developed in Canada and is aimed at modeling of heat conduction or heat convection in saturated or unsaturated soils and is based on the finite element method.

For mathematical modeling of thermal regime of the railway track, or the penetration of the zero isotherm into the structure of TB performed by this software product, a new railway track (Figure 3) was constructed that is, as already mentioned above, in terms of structural composition of the subgrade compatible with the real Experimental stand of DRETM II (Figure 2). As the structural thickness of the sub-ballast layer $\left(d_{\mathrm{pl}}=0.45 \mathrm{~m}\right)$ in the experimental stand corresponds with the design frost index valid for the area of the town of Žilina $\left(I_{\mathrm{F}, \mathrm{d}}=-450^{\circ} \mathrm{C} \cdot\right.$ day $)$, it was necessary to modify the design of numerical models for design thickness of the frost index valid for the town of Poprad $\left(I_{\mathrm{F}, \mathrm{d}}=-650^{\circ} \mathrm{C} \cdot\right.$ day $)$ that, for this particular case according to TNŽ 73 6312:2005 (Directorate General of the Railways of the Slovak Republic, 2005), is $0.60 \mathrm{~m}$ (for unfavorable water regime).

If relevant input parameters are entered, using the software product it is possible to model various types of TB structures. Among the input parameters for mathematical modeling of thermal regime of the structure of railway tracks we include thermal and technical performance of materials incorporated in individual structural layers (thermal conductivity coefficient $(\lambda)$, specific heat capacity $\left(c_{0}\right)$, humidity $\left(w_{\mathrm{m}}\right)$, bulk density $\left(\rho_{0}\right)$ and temperature $(\theta)$ ), climatic parameters (average daily air temperatures $\left(\theta_{\mathrm{s}}\right)$, the surface of the ballast bed $\left(\theta_{\mathrm{bb}}\right)$, frost index $\left(I_{\mathrm{F}}\right)$, the thickness of snow cover $\left.\left(T_{\text {snow }}\right)\right)$, etc.

Verification of the above mentioned input parameters has been researched at DRETM for many years so far, but the most difficult input parameter is the thermal and technical performance of the first structural layer,

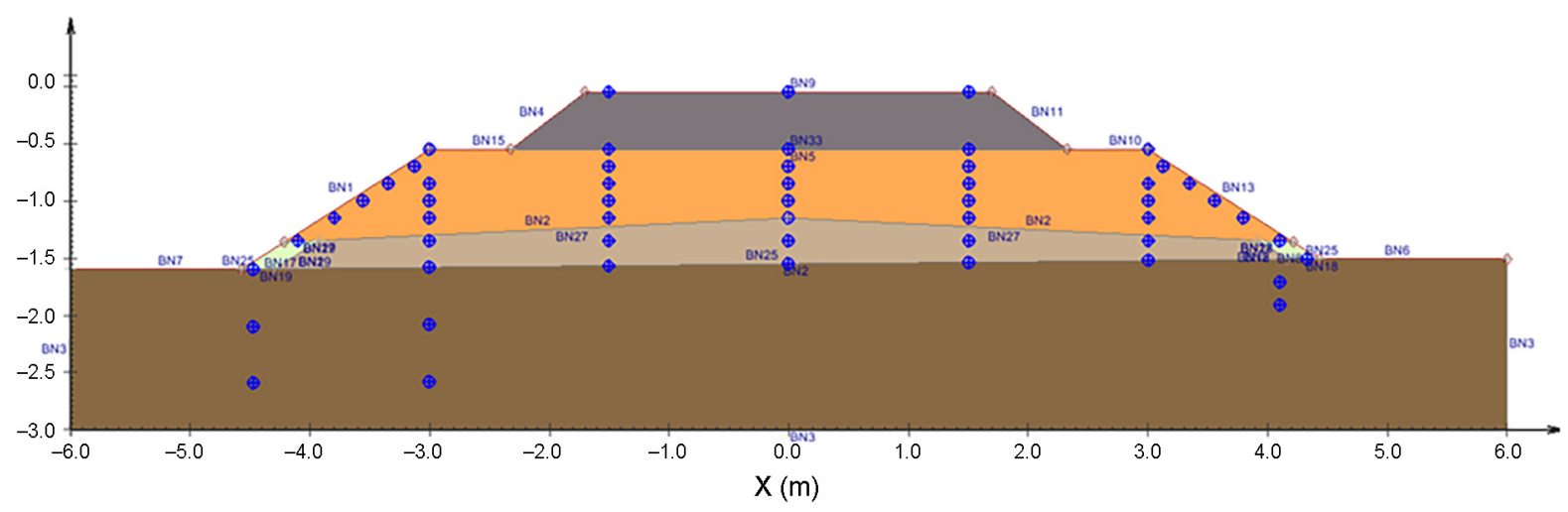

Figure 3. Cross section of the modified Experimental stand of DRETM II (Hodas, Ižvolt, \& Dobeš, 2016) 
precisely the ballast bed material. According to the TNŽ 73 6312: 2005 (Directorate General of the Railways of the Slovak Republic, 2005), the thermal conductivity coefficient $\left(\lambda=2 \mathrm{~W} \cdot \mathrm{m}^{-1} \cdot \mathrm{K}^{-1}\right)$ has been considered for the ballast bed, whereas it is not known yet what boundary conditions this value has been established for, namely what specific heat capacity of the material has been considered and also whether the value corresponds to clean or contaminated ballast bed. Experimental research has revealed that the level of contamination of the ballast bed has a major impact on the value of $\lambda$ and consequently after verification done by mathematical modeling it is also the depth of the frost penetration into TB structure $\left(D_{\mathrm{F}}\right)$.

Legislative documents valid for LG do not consider thermal conductivity coefficient $(\lambda)$ at all, they only include thermal conductivity coefficients for individual rock used for railway ballast bed (granite, dolomite, etc.). In view of this, based on the analysis of individual values mentioned, there was, for the purpose of mathematical modeling of the thermal regime of the railway track to Lithuanian conditions, the value of thermal conductivity coefficient $(\lambda=$ $1.68 \mathrm{~W} \cdot \mathrm{m}^{-1} \cdot \mathrm{K}^{-1}$ ) specified applicable to clean ballast bed and for Slovakia there was the value $0.7 \mathrm{~W} \cdot \mathrm{m}^{-1} \cdot \mathrm{K}^{-1}$ determined for clean ballast bed and the value $1.1 \mathrm{~W} \mathrm{~m}^{-1} \mathrm{~K}^{-1}$ for contaminated ballast bed (The same methodology for the determination of the coefficient was used for other materi- als as well, however, from the materials used in the structure of a TB, only the ballast bed showed significant differences from the reference values). Obviously, the values of the thermal conductivity coefficient $(\lambda)$ considerably differ, therefore values of various frost penetrations into the structure of TB were predicted and they have been verified by mathematical modeling of its thermal regime. Within the mathematical modeling there were in total four simulations were performed of the zero isotherm penetration into the TB structure model are shown in Figure 3. The input parameters for modeling were the same (Table 2), characteristics that have changed were the parameters of the ballast bed (thermal conductivity coefficient, specific heat capacity, bulk density and humidity) - Table 3 .

For mathematical modeling of frost penetration into the TB structure there was the already above mentioned course of the winter season in Lithuania in the years 19851986 applied characterized by a specific values of average daily temperatures and by the maximum frost index reached in Dükštas (measured value $I_{F}=-633^{\circ} \mathrm{C} \cdot$ day).

The individual course of each simulation contains a total of 151 days where day 1 (TIME $=1)$ corresponds to the date of November 01, 1985 and the last day $($ TIME $=151)$ corresponds to the date of March 31, 1986. Figure 4 illustrates a moment (a day) when the maximum values of frost penetration into the structure were reached for boundary

Table 2. Input characteristics of structural layers of the track substructure body

\begin{tabular}{|c|c|c|c|c|}
\hline Construction Part/Characteristics & Sub-ballast layer & Embankment & Foundation & Clay \\
\hline Designation in the model & $\mathrm{R} 2$ & R3 & $\mathrm{R} 4$ & $\mathrm{R} 5, \mathrm{R} 6$ \\
\hline Temperature $\theta,{ }^{\circ} \mathrm{C}$ & 11 & 12 & 14 & 6 \\
\hline Humidity $w_{m}, \%$ & 5.0 & 5.0 & 16,0 & 20.0 \\
\hline Specific heat capacity $c_{0}, \mathrm{~J} \cdot \mathrm{kg}^{-1} \cdot \mathrm{K}^{-1}$ (Ižvolt, Dobeš, \& Mečar, 2013) & 1088 & 1053 & 1495 & $\begin{array}{c}1639 \\
1305^{\star} \\
\end{array}$ \\
\hline Bulk density $\rho_{0}, \mathrm{~kg} \cdot \mathrm{m}^{-3}$ (Ižvolt et al., 2013) & 1928 & 2091 & 1646 & 1320 \\
\hline Thermal conductivity coefficient $\lambda, \mathrm{W} \cdot \mathrm{m}^{-1} \cdot \mathrm{K}^{-1}$ (Ižvolt et al., 2013) & 1.55 & 1.42 & 0.81 & $\begin{array}{c}1.13 \\
1.35^{\star}\end{array}$ \\
\hline
\end{tabular}

Note: ${ }^{\star}$ Values for frozen material.

Table 3. Input characteristics of the ballast bed

\begin{tabular}{|l|c|c|c|c|}
\hline \multicolumn{1}{|c|}{ Construction Part/Characteristics } & \multicolumn{3}{c|}{ Ballast Bed } \\
\cline { 2 - 6 } & $\begin{array}{c}\text { Simulation } \\
\text { No. } 1\end{array}$ & $\begin{array}{c}\text { Simulation } \\
\text { No. } 2\end{array}$ & $\begin{array}{c}\text { Simulation } \\
\text { No. } 3\end{array}$ & $\begin{array}{c}\text { Simulation } \\
\text { No. } 4\end{array}$ \\
\hline Designation in the model & R1 & R1 & R1 & R1 \\
\hline Temperature $\theta,{ }^{\circ} \mathrm{C}$ & 7 & 7 & 7 & 7 \\
\hline Humidity $w_{m}, \%$ & 5.0 & 1.3 & 4.0 & 1.4 \\
\hline Specific heat capacity $c_{0}, \mathrm{~J}_{\mathrm{kg}}{ }^{-1} \cdot \mathrm{K}^{-1}$ & 1010 & 1095 & 1010 & 940 \\
\hline Bulk density $\rho_{0}, \mathrm{~kg} \cdot \mathrm{m}^{-3}$ & 1870 & 2198 & 1870 & 1730 \\
\hline Thermal conductivity coefficient $\lambda, \mathrm{W} \cdot \mathrm{m}^{-1} \cdot \mathrm{K}^{-1}$ & 2.00 & 1.68 & 1.10 & 0.70 \\
\hline State of the material & contaminated & clean & contaminated & clean \\
\hline
\end{tabular}




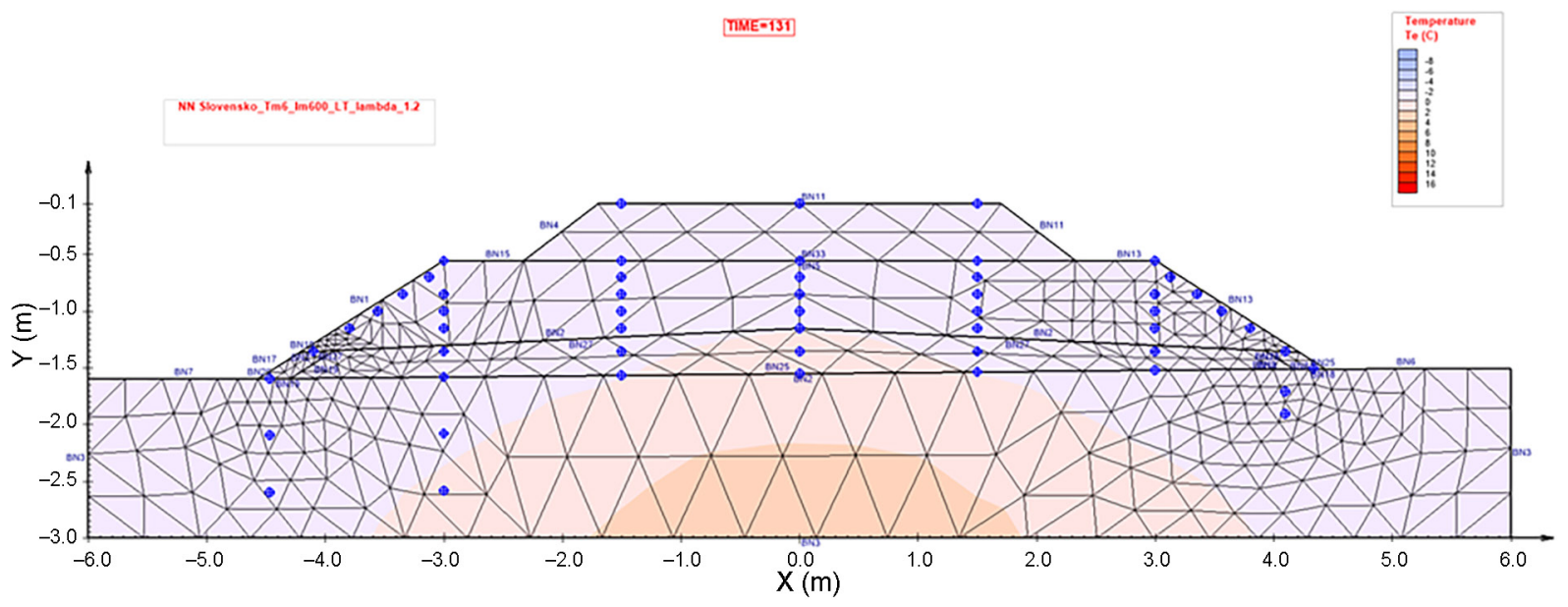

Figure 4. Simulation No. 3 on a day when the greatest depth of the structure frost penetration was reached

conditions of the Simulation No. 3 that was in the order the $131^{\text {st }}$ day of the respective winter season (TIME $\left.=131\right)$.

Table 4 presents the results of mathematical modeling developed for individual simulations, i.e. the greatest depths of frost penetration of the TB reached and the necessary thickness of the sub-ballast layer associated with them.

Table 4. Reached depths of the frost penetration into the model structure of the railway track and the resulting required thicknesses of the sub-ballast layer

\begin{tabular}{|c|c|c|}
\hline $\begin{array}{c}\text { Simulation } \\
\text { No. }\end{array}$ & $\begin{array}{c}\text { Depth of the frost } \\
\text { penetration } \\
D_{F}, \mathrm{~m}\end{array}$ & $\begin{array}{c}\text { Required thickness of } \\
\text { the sub-ballast layer } \\
d_{p l, r}, \mathrm{~m}\end{array}$ \\
\hline 1 & 1.56 & 1.05 \\
\hline 2 & 1.41 & 0.90 \\
\hline 3 & 1.12 & 0.60 \\
\hline 4 & 0.85 & 0.35 \\
\hline
\end{tabular}

From Table 4 it is clear that the required thickness of the sub-ballast layer $0.60 \mathrm{~m}$ corresponds with the value of the thermal conductivity coefficient $\lambda=1.1 \mathrm{~W} \cdot \mathrm{m}^{1} \cdot \mathrm{K}^{-1}$, considered in Simulation No. 3, which is coincidentally identical with the value determined in the laboratory of DRETM. At the same time, it was confirmed that the required thickness of the sub-ballast layer structure according to the methodology of ŽSR corresponding with the thermal conductivity coefficient $\lambda=2.0 \mathrm{~W} \cdot \mathrm{m}^{-1} \cdot \mathrm{K}^{-1}$ by its thickness of $0.60 \mathrm{~m}$ is undersized by $75 \%$, since by mathematical modeling it is evident that the structural thickness of the sub-ballast layer should be thicker, i.e. instead of $0.60 \mathrm{~m}$ it should be $1.005 \mathrm{~m}$. For RL conditions, if the value of the considered thermal conductivity coefficient is $\lambda=1.68 \mathrm{~W} \cdot \mathrm{m}^{-1} \cdot \mathrm{K}^{-1}$, the calculation of the structural thickness of the sub-ballast layer is about $50 \%$ thicker, i.e. instead of $0.60 \mathrm{~m}$ it should be $0.90 \mathrm{~m}$.

\section{Discussion}

The main objective of the measurements to achieve a sufficient resistance of the track bed structure to the action of the transport and non-transport load is to affect or preferably to remove completely factors causing its damage. One of the main measurements in order to be able to achieve the necessary resistance of the track bed structure is the proposal of correct sub-ballast layer thickness. As it is clear from the comparison of the design methodologies used in Slovakia and Lithuania on dimensions design of the sub-ballast layer of a TB (see Table 1), the draft design of the subbase layer thickness that is based on the dimensioning of the TB structure for traffic load, in general, for the tracks of Lithuania its smaller structural thickness is calculated if compared to the thickness of the subbase layer based upon the prescribed methodology used in Slovakia, namely it is the structural thickness of 0.25 , or $0.20 \mathrm{~m}$ (LG) compared to $0.20-0.50 \mathrm{~m}$ (ŽSR). Self-comparison is irrelevant here, since the structure dimensions design methodologies are not based on the same boundary conditions of the design, whereas the main difference lies in the modules of deformation of materials that are envisaged to be used for the subbase layer and in the fact that these modules are determined by different methodologies and test procedures. Anyway, in the application of the minimum thickness, these values are roughly identical.

In the draft design of the thickness in terms of the nontransport load, the proposed structural thickness of the sub-ballast upper surface of a new track structure is identical for the considered air frost index $I_{F}=-650{ }^{\circ} \mathrm{C} \cdot$ day and it reaches the value of $0.60 \mathrm{~m}$. One should state here that the dimensioning of the structure of the TB for nontransport load is in legislative documents of both countries processed only poorly or it does not reflect new materials used in the structure of the sub-ballast layer and also the changes in climatic conditions that have been moni- 
tored for longer period of time so far. In addition, the draft design of the sub-ballast layer thickness for the tracks of LG is realized only by the nature of the areas of frost. The method of structure dimensions design was created by an adjustment of methods of designing used at German railways DB A.G. (DS 836, 1999), where the structural thickness of the sub-ballast layer is provided also a tabular form, depending on the areas of frost using design maps of the division of the country of Germany into the areas of winter period intensity (taking into account the average annual temperature and frost indices), but in Lithuania a similar design map has not been processed yet.

Dimensions design of the TB structure for non-transport load used at ŽSR tracks is relatively more correct. Structural thickness of the sub-ballast layer is determined upon the basis of design nomograms always valid for a certain velocity range and degree of frost susceptivity of a soil, depending on frost indices, needed to say that for the territory of the Slovakia a design map of frost indices has already been processed. The drawback, however, is that draft design of the sub-ballast layer thickness is carried out for the coldest winter that has ever been recorded at weather stations for the last 50 years. Given that, at this time we are in 2017, it is clear that the presented design map of frost indices, does not apply to current period because it contains frost indices reached in the winter season of 1960/1961 and at the same time does not it reflect the anticipated climatic changes - discussed global warming of the Earth.

Another drawback in the methodology of designing the TB structure for non-transport load of both countries is the fact that the draft design of the structural thickness of the sub-ballast layer is essentially affected by the only parameter; the frost index. Research activities in Germany and at DRETM as well found out that the frost index is not the only parameter affecting the frost penetration depth into to the structure of the TB and hence the depth of the frozen layer. Based on these studies it is clear that in the design methodology it would be useful to take into account also the impact of the average annual temperature, humidity of the respective structural layers of the TB of a railway track which in service conditions is strongly influenced by the level of contamination primarily of the track ballast material, presence and thickness of the snow cover, the accumulated heat in the TB before the cooling and freezing processes of the railway track start.

Monitoring course of load tests or frost penetration into the structure of the railway track, monitoring the course of vertical stress or the level of the zero isotherm penetrating into the track bed and verification of the design methodology of dimensioning of the track bed structure for transport and non-transport load can be carried out by experimental measurements in situ or in laboratory conditions at the available experimental stands. In particular, experimental measurements and monitoring of the effects of non-transport load on the railway track, i.e. climatic influences, particularly those of water and frost, is very time consuming. Current possibilities in the field of computer technology make it possible, in addition to viewing of individual structural layers of the TB for specific transport and non-transport load on the real track sections, also to utilize the appropriate and available software products by the application of which it is possible in a relatively short period of time to model various cases and types of structure of a railway track that are subject to different values and courses of transport and non-transport load. To be able to achieve objective results, relevant input data have always been necessary but the situation is that for all the available materials currently applied in the structure of a railway track (TB) these input data are not known yet, or there are not the same criteria on their physical and mechanical properties and the state when we would assess values at which they conform to track operated (e.g. a degree of contamination of the track ballast bed or material of the sub-ballast layer).

\section{Conclusions}

In terms of the mathematical modeling of non-transport load the most serious deficiency is the absence or inaccuracy of the relevant thermal and technical parameters used in the structural layers of a railway track and in the embankment in their basement. Moreover, in the methodology of dimensioning the TB of the RL railway tracks the relevant input parameters are missing in the legislative documents completely (for the design, parameters obtained by the research have been used). In the methodology used for dimensioning at ŽSR, the parameters are available, but what is not known are the boundary conditions and the methodology how they had been determined. What is essential is the fact that, for example, the values of the thermal conductivity coefficient $(\lambda)$ for material of the ballast bed - track ballast - as stated for the process of structure dimensions designing of the subballast layer for railway tracks administered by ŽSR and LG are very different, which in turn has a major impact on the thermal resistance of the structural layer of the ballast bed, and thus the zero isotherm penetration into the structure of the railway track. In the methodology of dimensioning of the TB structure for ŽSR tracks there is the thermal conductivity coefficient of track ballast (granite) stated as $\lambda=2.0 \mathrm{~W} \cdot \mathrm{m}^{-1} \cdot \mathrm{K}^{-1}$ for the $\mathrm{LG}$ railway tracks one should consider the value of $\lambda=1.68 \mathrm{~W} \cdot \mathrm{m}^{-1} \cdot \mathrm{K}^{-1}$ whereas the experimental measurements in the laboratory of DRETM proved the value of the thermal conductivity coefficient of the track ballast to be $\lambda=0.7 \mathrm{~W} \cdot \mathrm{m}^{-1} \cdot \mathrm{K}^{-1}$ applicable to a clean ballast bed and $\lambda=1.1 \mathrm{~W} \cdot \mathrm{m}^{-1} \cdot \mathrm{K}^{-1}$ for a contaminated one. Given the fact that the input values of the thermal conductivity coefficient $(\lambda)$ for mathematical modeling are so different, we have performed the comparison of the required thickness of the sub-ballast layer for the ŽSR and LG tracks for valid standard values and also the values based upon the research. The result of the mathematical modeling of thermal regime of the structure of a railway track is evident from the Table 4, where the most likely value of the thermal conductivity coefficient 
$(\lambda)$ of the ballast bed material - track ballast - which could be acceptable for a relevant structure dimensions designing of the TB for non-transport load is the value of $\lambda=1.1 \mathrm{~W} \cdot \mathrm{m}^{-1} \cdot \mathrm{K}^{-1}$ obtained by experimental measurements at DRETM on samples of a contaminated ballast material of humidity $w=4 \%$.

For this value, based upon a mathematical model commencing from a structural arrangement of the railway track shown in Figure 2, or the one in Figure 3, the achieved depth of frost penetration into the structure of a railway track $D_{\mathrm{F}}=1.12 \mathrm{~m}$, which means that the required structural thickness of the sub-ballast layer $0.60 \mathrm{~m}$ is equal to the design thickness resulting from the methodology of dimensioning for not-transport load applied at ŽSR generally for a new structure and a reconstruction of the railway of a velocity range VR $4(120 \mathrm{~km} / \mathrm{h}<V \leq 160 \mathrm{~km} / \mathrm{h})$ and in case of the LG tracks of the same speed limit for their new structures.

In any case, methods of designing the TB not only for non-transport load, but also for the transport load used at ŽSR and LG need to be amended not only because of new findings and knowledge in the field of dimensions design of multilayer structures, but also for the use of new building materials in the structure of the TB and because of an increased demand on the quality of railway tracks in relation to their inevitable modernization, and for the future, in connection with the structure of high-speed or highspeed tracks in Slovakia and in Lithuania as well.

\section{References}

AB "Lietuvos geležinkeliai” (LG). (2013). Apsauginio sankasos sluoksnio įrengimo instrukcija (275/K). Patvirtinta AB „Lietuvos geležinkeliai” genrealinio direktoriaus 2013 rugsëjo $6 \mathrm{~d}$. ìsakymu Nr. İ-827 (in Lithuanian).

Bai, L., Liu, R., Sun, Q., Wang, F., \& Xu, P. (2015). Markov-based model for the prediction of railway track irregularities. Proceedings of the Institution of Mechanical Engineers. Part F: Journal of Rail and Rapid Transit, 229(2), 150-159. https://doi.org/10.1177/0954409713503460

Bureika, G., Gaidamauskas, E., Kupinas, J., Bogdevičius, M., \& Steišunas, S. (2016). Modelling the assessment of traffic risk at level crossings of Lithuanian railways. Transport, 32(3), 282290. https://doi.org/10.3846/16484142.2016.1244114

Deutsche Bundesbahn. (1999). Vorschrift für Erdbauwerke, VE (DS 836).

Deutsches Institut für Normung. (1993). Plattendruckversuch, Baugrund, Versuche und Versuchsgeräte (DIN 18 134). Germany.

Directorate General of the Railways of the Slovak Republic. (2005). Proposed construction design of the subgrade layers (TNŽ 73 6312) (in Slovak).

Dobeš, P. (2015). Optimization of the subgrade design for nontraffic load (Doctoral dissertation). University of Žilina, Faculty of Civil Engineering, Department of Railway Engineering and Track Management.

Giner, G. I., Alvarez, R. A., Garcia-Moreno, S. C. S., \& Camacho, L. J. (2016). Dynamic modelling of high speed ballasted railway tracks: analysis of the behavior. In XII Conference on Transport Engineering (CIT 2016), Valencia, Spain. https://doi.org/10.1016/j.trpro.2016.12.058
Gu, G., \& Choi, J. (2013). The dynamic response of rail support. Vehicle System Dynamics, 51(6), 798-820. https://doi.org/10.1080/00423114.2013.778415

Hodas, S., Ižvolt, L., \& Dobeš, P. (2016). Preliminary results and conclusions from mathematical modelling of thermal regime of railway track structure. International Journal of Computational Methods and Experimental Measurements, 4(2), 69-79. https://doi.org/10.2495/CMEM-V4-N2-69-79

Ižvolt, L. (2008). Railway substructure - stress, diagnostics, design and implementation of body construction layers of railway subgrade (Scientific monograph). University of Žilina (in Slovak).

Ižvolt, L., \& Dobeš, P. (2015). Experimental monitoring of moisture changes in railway track structure. In TRANSCOM 2015: 11-th European Conference of Young Researchers and Scientists (pp. 46-51).

Ižvolt, L., Dobeš, P., \& Mečar, M. (2013). Contribution to the methodology and verification of the thermal conductivity coefficients $\lambda$ of selected materials of subgrade structure. Civil and Environmental Engineering, Scientific Technical Journal of $S v F, 2,102-114$.

Ižvolt, L., Dobeš, P., \& Pitoňák, M. (2014). Some experience and preliminary conclusions from the experimental monitoring of the temperature regime of subgrade structure. Computer in Railways XIV: Railway Engineering Design and Optimization, 135, 267-278. https://doi.org/10.2495/CR140211

Ižvolt, L., Dobeš, P., \& Pitonak, M. (2017). Preliminary results and conclusions from the experimental monitoring of thermal regime of railway track structure. International Journal of Transport Development and Integration, 1(3), 529-539. https://doi.org/10.2495/TDI-V1-N3-529-539

Ižvolt, L., Dobeš, P., \& Pultznerová, A. (2016). Monitoring of moisture changes in the construction layers of the railway substructure body and its subgrade. Procedia Engineering, 161, 1049-1056. https://doi.org/10.1016/j.proeng.2016.08.847

Navikas, D., \& Sivilevičius, H. (2017). Modelling of snow cover thickness influence on the railway construction temperature regime under variable weather conditions. Procedia Engineering, 187, 124-134. https://doi.org/10.1016/j.proeng.2017.04.358

Navikas, D., Bulevičius, M., \& Sivilevičius, H. (2016). Determination and evaluation of railway aggregate sub-ballast gradation and other properties variation. Journal of Civil Engineering and Management, 22(5), 699-710. https://doi.org/10.3846/13923730.2016.1177586

Nguyen, K., Goicilea, J. M., \& Galbadon, F. (2014). Comparsion of dynamic effects of high-speed traffic load on ballasted track using a simplified two dimensional and full three-dimensional model. Proceedings of the Institution of Mechanical Engineers. Part F: Journal of Rail and Rapid Transit, 228(2), 128-142. https://doi.org/10.1177/0954409712465710

Podvezko, V., \& Sivilevičius, H. (2013). The use of AHP and rank correlation methods for determining the significance of the interaction between the elements of a transport system having a strong influence on traffic safety. Transport, 28(4), 389403. https://doi.org/10.3846/16484142.2013.866980

Slovak Office of Standards, Metrology and Testing. (1980). Static load test of subgrade and base layers of roads (STN 73 6190). Slovak Republic (in Slovak).

SoilVision systems Ltd. (2009). SV-HEAT - 2D/3D Geothermal Modeling, SVOFFICE 2009 - Geotechnical Modeling Suite. Saskatoon, Saskatchenwan.

Yang, G. T., Ke, Z. T., Cai, D. G., You, H. Y., Yao, J. P., \& Chen, F. (2015). Investigation of monitoring system for high-speed railway subgrade frost heave. Sciences in Cold and Arid Regions, 7(5), 528-533. 